\title{
The effects of the reverse seasonal flooding on soil texture within the hydro-fluctuation belt in the Three Gorges reservoir, China
}

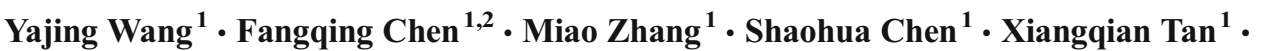 \\ Meng Liu ${ }^{1} \cdot \mathrm{Zhihua} \mathrm{Hu}^{2}$
}

Received: 16 January 2017 / Accepted: 30 April 2017 /Published online: 21 May 2017

(C) The Author(s) 2017. This article is an open access publication

\begin{abstract}
Purpose The formation of the large hydro-fluctuation belt at the altitude of 145-175 m, following the construction of the Three Gorges Dam, developed from the terrestrial system in the Three Gorges reservoir. This research mainly concerned the effects of the resultant reverse seasonal flooding on soil texture.

Materials and methods Four field experimental plots were designed with sample belts and quadrats at the head, middle, and tail sections of the reservoir area. Stratified soil samples were collected, followed by analysis of soil structure and soil grain size of the collected samples.

Results and discussion The reverse seasonal flooding significantly changes texture and nutrient of riparian soil. The percentages of silt and clay formations were greatest at the lower hydro-fluctuation belt, followed by the middle and upper hydro-fluctuation belt, respectively. The percentage of silt and clay particles at $150 \mathrm{~m}$ was greater than that of $170 \mathrm{~m}$ by $18.12 \%$. Conversely, the percentage of sand particles at the upper hydro-fluctuation belt ranked the highest, and followed by the middle and lower hydro-fluctuation belt, respectively. The percentage of sand particles at $170 \mathrm{~m}$ was higher than that
\end{abstract}

Responsible editor: Rainer Horn

Fangqing Chen

fqchen@ctgu.edu.cn

1 Hubei International Scientific and Technological Cooperation Center of Ecological Protection and Management in the Three Gorges Area, China Three Gorges University, Beijing, People's Republic of China

2 Hubei Zhengjiang Environmental Science and Technology Co., Ltd, Xihu Road 32, Yichang, Hubei Province 443002, People's Republic of China at $150 \mathrm{~m}$ by $19.72 \%$. Soil texture type changed with increasing altitude gradient, from silt loam, loam, then to sandy loam. Reverse seasonal flooding also promotes silt and clay permeation, and deposition from surface soil to subsurface soil, increasing homogeneity in grain structure between soil layers. This change in soil texture is associated with changes in soil nutrients. The content of soil organic matter, total nitrogen, total phosphorus, and total potassium varied significantly among soil texture types, with loam having the highest soil nutrient concentration and sandy loam having the lowest.

Conclusions The reverse seasonal flooding promotes the deposition of clay and silt within the hydro-fluctuation belt, inducing the total texture change of loam to silt loam. However, the structures and attributes of soil texture varied along the altitude gradient, as the exposed and submersed season and time span of riparian soil changed with the increase of altitude.

Keywords Soil composition · Soil nutrient · Soil grain size · Spatial distribution · The Three Gorges project

\section{Introduction}

Soil texture is a critical indicator of soil physical properties, characterizing soil composition of different sized mineral particles (Neyshabouri et al. 2011; Wang et al. 2014). These soil particles form soil aggregates by combining with organic matter through cementation and agglomeration. The formation of aggregates increases organic matter stability and reduces their rate of decomposition. The size and percentage of soil particles significantly influence the size and quantity of soil aggregates, as well as their integration with organic matter (Ahmadi et al. 2011). From previous studies, there is a clear dependency of soil organic matter on soil particle size (Crawford et al. 1993; Zheng et al. 2011), in 
that high relative percentages of smaller particles (clay and silt) in soil result in reduced organic matter decomposition rates and higher organic matter content (Lin and Li 2001). Predictably, organic content is commensurately lower with high soil concentrations of larger particles such as sand (Christensen and Straw 1986; Wang et al. 2007). As such, soil texture is thought of as a critical factor in determining soil fertility due to its consequences on soil nutrient content and aeration conditions (Wang et al. 2003; Xu et al. 2013).

Soil texture is determined primarily by the soil's stable parent material types. In addition to these basic properties, soil texture can also be modified dramatically by specific environmental factors (Wang et al. 2003; Wang et al. 2009; Fu et al. 2012). Flooding is an important environmental factor which has crucial effects on changes of soil texture and soil nutrients in riverbank ecosystem (Neill 1995; Hefting et al. 2004; Yang et al. 2006). Some previous studies indicated that flooding could promote soil particles depositing on riverbanks and improve soil physical and chemical properties (Banach et al. 2009; Lee et al. 2014; Lu et al. 2016). However, other studies suggested that flooding induced the degradation of soil texture as it washed away much smaller soil particles (Campbell et al. 2002). It was thought that the variances of flooding pattern and riverbank altitude contributed to the different research results (Saint-Laurent et al. 2014; Ye et al. 2014).

With the construction of the Three Gorges project in China, the water level in the reservoir area has been greatly raised, and a large number of terrestrial ecosystems (from altitude 145 to $175 \mathrm{~m}$ ) have been transformed into a riparian ecosystem, forming a new hydro-fluctuation belt of over $400 \mathrm{~km}^{2}$. The amplitude and rhythm of flooding changed dramatically, with amplitude increasing from 10 to $30 \mathrm{~m}$, and flooding rhythm reversing from "summer submersion-winter exposure" to "summer exposure-winter submersion." Due to the disturbance caused by this reverse seasonal flooding, the riparian environment was changed dramatically. These brought about the further, significant degradation of the riparian ecosystem, resulting in the loss of complexity within the composition and structure of the plant community (Lu et al. 2007, 2010). Along with decreased soil nutrient quality, a spatial heterogeneity of soil nutrient content also appeared (Guo et al. 2012). We hypothesize that the reverse seasonal flooding also correspondingly impact the soil texture within the hydro-fluctuation belt in the Three Gorges reservoir area. We selected four typical sections along Yangtze river in the Three Gorges reservoir area as case study plots, with soil samples collected along the elevation gradient from each plot, and the particle size composition of soils samples was tested. The effects of the reverse seasonal flooding on soil texture were elucidated by analyzing the changes in soil texture with altitude gradient and soil depth. Coordinated changes in soil nutrient were also analyzed in conjunction with the spatial distribution of soil nutrient characteristics.

\section{Materials and methods}

\subsection{Research plots}

Four field experimental plots were allocated along the Yangtze river in the Three Gorges reservoir area, located in Zigui and Xingshan counties in the Hubei province, and Wanzhou city and Zhongxian county in the Chongqing municipal (Fig. 1). The general environmental conditions in the four field plots are as follows:

(1) Zigui hydro-fluctuation belt at $30^{\circ} 38^{\prime} 58^{\prime \prime} \mathrm{N}$ and $110^{\circ} 18^{\prime} 23^{\prime \prime}$ E. Average annual temperature is approximately $18.9^{\circ} \mathrm{C}$, with an average annual rainfall of $1100 \mathrm{~mm}$ and average annual sunshine time of $1631.5 \mathrm{~h}$. Soil texture type is Haplic alisol $30 \mathrm{~cm}$ thick, with a riverbank slope of about $30^{\circ}$. The plant habitat is composed primarily of grass dominated by Setaria viridis, Rumex dentatus, and Digitaria ciliaris etc.

(2) Xingshan hydro-fluctuation belt at $31^{\circ} 06^{\prime} 26^{\prime \prime} \mathrm{N}$ and $110^{\circ} 55^{\prime} 47 \mathrm{E}$. Average annual temperature is approximately $15.3{ }^{\circ} \mathrm{C}$, with an average annual rainfall of $1050 \mathrm{~mm}$, and an average annual sunshine time of $1682.8 \mathrm{~h}$. The soil texture type is Haplic luvisol $30 \mathrm{~cm}$ thick, with a riverbank slope of about $28^{\circ}$. The plant habitat is composed of grass dominated by Cynodon dactylon, Psapalum distichum, and Rumex dentatus.

(3) Wanzhou hydro-fluctuation belt at $30^{\circ} 43^{\prime} 31 \mathrm{~N}$ and $108^{\circ} 25^{\prime} 43^{\prime \prime}$ E. Average annual temperature is about $17.7^{\circ} \mathrm{C}$, with an average annual rainfall of $1243 \mathrm{~mm}$, and an average annual sunshine time of $1484.4 \mathrm{~h}$. The soil texture type is Haplic luvisol $40 \mathrm{~cm}$ thick, with a riverbank slope of about $25^{\circ}$. The plant habitat comprised grass dominated by Cynodon dactylon, Alternanthera philoxeroides, and Setaria viridis.

(4) Zhongxian hydro-fluctuation belt at $30^{\circ} 24^{\prime} 51^{\prime \prime} \mathrm{N}$ and $108^{\circ} 18^{\prime} 29^{\prime \prime}$ E. Average annual temperature is about $18.2^{\circ} \mathrm{C}$, with an average annual rainfall of $1200 \mathrm{~mm}$ and an average annual sunshine of $1327.5 \mathrm{~h}$. The soil type is Haplic luvisol $50 \mathrm{~cm}$ thick, with a riverbank slope of about $22^{\circ}$. The plant habitat is dominated by Hemarthria sibirica, Cynodon dactylon, and Polygonum viscosum.

\subsection{Quadrat design and sample collection}

The field experiment was conducted on March 2014 following flood recession and the reappearance of the hydrofluctuation belt in the Three Gorges reservoir area. Seven sample belts were designed at each plot along the elevation gradient within the altitudes of $150-180 \mathrm{~m}$ at an altitude 


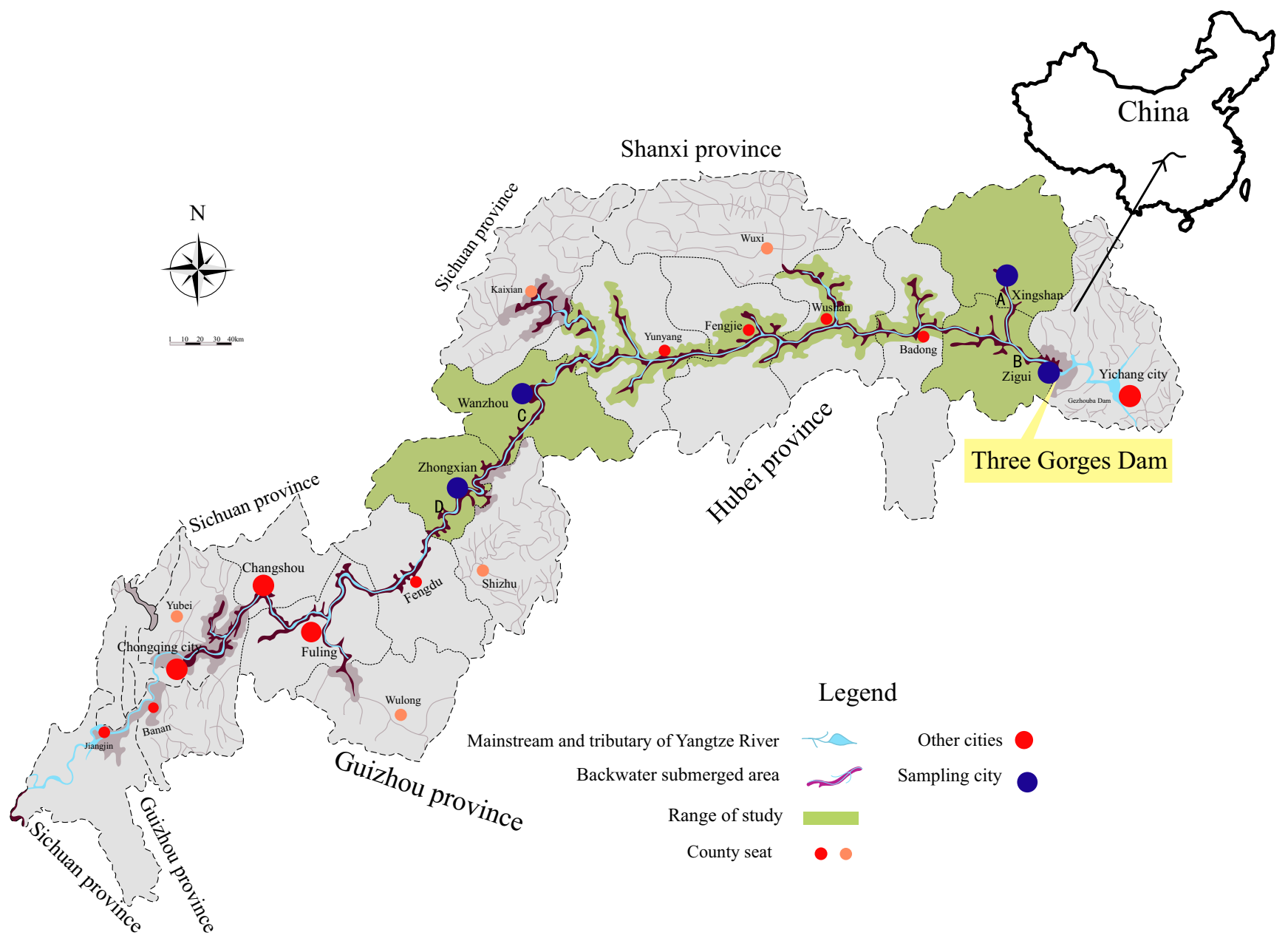

Fig. 1 Distribution of the field experimental plots in the Three Gorges reservoir area

distance of $5 \mathrm{~m}$. Ten quadrats $\left(1 \times 1 \mathrm{~m}^{2}\right)$ were arranged randomly within each sample belt. Riverbank within the altitude of 150 $175 \mathrm{~m}$ was designated as the hydro-fluctuation belt, with the nonhydro-fluctuation belt above $175 \mathrm{~m}$ used as a control. Soil was sampled at the center and four corners in each quadrat using a soil collector (diameter in $8 \mathrm{~cm}$, length in $15 \mathrm{~cm}$ ) before soil litters were cleaned. Each collected soil column was divided into three sections $(0-5,5-10$, and $10-15 \mathrm{~cm})$ as the soil samples to represent varying soil depths. Five hundred and twenty-five soil samples were collected from each plot.

\subsection{Determination of soil texture and soil nutrient}

Soil samples were air-dried in a laboratory. Debris was removed from the samples, with stones and other impurities removed with 10 and $100 \mathrm{~mm}$ sieves one after another after being crushed and ground. The sieved soil samples were kept in plastic bags and stored in a refrigerator at $4{ }^{\circ} \mathrm{C}$. One section of each sample was used in determining soil texture, and the rest used for measuring the soil chemical properties. The composition of soil particle size was analyzed using a TopSizer laser particle size analyzer. Soil particles less than $2 \mu \mathrm{m}$ in size were classified as clay, particles between 2 and $20 \mu \mathrm{m}$ as silt, and particles of 20-2000 $\mu \mathrm{m} \mathrm{m}$ in size as sand. Soil organic matter content was tested through the method of potassium dichromate oxidation-heated externally. Total nitrogen concentrations were tested using the Kjeldahl determination, total phosphorus tested using the method of acid fusion-Mo sb colorimetry, and the total potassium tested using the method of $\mathrm{NaOH}$ melting-lame photometry.

\subsection{Data analysis}

ANOVA analysis (one-way ANOVA) was applied using the altitude gradient and soil depth as dependent variables and soil particles as an independent variable in order to analyze the variance of soil texture along altitude gradient. The Turkey test was employed when the effect of a single factor was significantly different between treatment groups in order to obtain further data. The soil texture type of soil samples was classified according to the international soil texture classification standard (Christensen and Straw 1986). The effect of flooding on soil texture was uncovered through the analysis of changes in soil particle 
composition and soil texture type along altitude gradient. The relationship between the changes of soil texture and soil nutrient was further discussed. All data were analyzed using SPSS19.0 software.

\section{Results}

\subsection{Effects of flooding on composition and type of soil texture}

The reverse seasonal flooding induced a significant change in soil texture composition, with soil percentages of clay, silt, and sand changing significantly $(P<0.01)$ (Table 1$)$. Compared with the non-flooding, the percentage of soil clay and silt in hydrofluctuation belt increased by 8.45 and $7.58 \%$ respectively, while the percentage of sand decreased by $7.47 \%$. The soil texture type changed completely from loam to silt loam along with the change of soil particle size composition.

\subsection{The changes of soil texture along an altitude gradient}

The soil particle size composition changed significantly along an altitude gradient $(P<0.01)$ (Table 2$)$, with a corresponding change taking place in soil texture type. In the lower hydrofluctuation belt $(150-155 \mathrm{~m})$, the percentage of the clay and silt ranged within 53.97 to $55.68 \%$, and the soil texture was classified as a silt loam; in the middle hydro-fluctuation belt (160$165 \mathrm{~m}$ ), the percentage of the clay and the silt ranged from 51.91 to $52.84 \%$, the soil texture belonged to loam; in the upper hydro-fluctuation belt (170-175 m), the percentage of the clay and silt in soil decreased slightly, ranging from 47.14 to $52.16 \%$. The soil texture of most soil samples was loam, but that of a few soil samples collected from $170 \mathrm{~m}$ were characteristic of sandy loam, in which the percentage of sand particles was over $55.0 \%$.

\subsection{The change of riparian soil texture with soil depth}

The particle size composition of riparian soil changed significantly in relation to soil depth $(P<0.01)$. The percentage of clay and silt in soil increased with soil depth, while the percentage of sand decreased. The soil texture type of topsoil was loam within the riverbank, while that of middle layer soil and subsoil was silty loam. However, the change in soil particle size composition in relation to soil depth differed significantly between the hydro-fluctuation belt and non-hydro-fluctuation belt (Table 3). In the hydro-fluctuation belt, the percentage of clay and silt in topsoil was 8.72 and $5.68 \%$ lower, respectively, than that of middle layer soil, and 12.09 and $73.69 \%$ lower than that of subsoil. The percentage of sand in topsoil was higher than that of the middle layer soil and subsoil by 7.30 and $9.74 \%$, respectively. In the non-hydro-fluctuation belt, the percentage of clay and silt in topsoil was 12.50 and $9.73 \%$ higher than that of middle layer soil and 18.14 and $14.16 \%$ higher than that of subsoil. The percentage of sand in topsoil was higher than that in the middle layer soil and subsoil by 8.18 and $20.81 \%$, respectively. The reverse seasonal flooding reduced the difference in soil particle size composition between topsoil, middle layer soil, and subsoil.

\subsection{Nutrient characteristics of different soil texture in hydro-fluctuation belt}

There were significant discrepancies in soil nutrient content between the three soil texture types that appeared in the hydrofluctuation belt $(P<0.01)$ (Table 4$)$. The soil nutrient of loam ranked the highest, followed by silty loam and sand loam. The soil content of organic matter, total nitrogen, total phosphorus, and total potassium of loam was higher than that of silty loam by $12.54,17.64,12.12$, and $10.03 \%$, respectively, and higher than that of sand loam soil by $46.11,34.24,46.05$, and $66.61 \%$.

\section{Discussion}

\subsection{The effect of the reverse seasonal flooding on soil texture}

Soil texture type was influenced by the internal factor of soil parent material, as well as by many external factors such as climate, water, vegetation etc. in the process of wetland evolution and recovery (Zheng et al. 2011; Wolf et al. 2011). The conditions of change in soil texture are difficult to isolate due to the influence of flooding in wetlands (Wang et al. 2005; Hossler and Bouchard 2010). While some studies suggest that flooding increased the percentage of clay particles and porosity of soil, leading to overall improvement soil texture ( $\mathrm{Lu}$ et al. 2007; Hossler and Bouchard 2010; Lee et al. 2014), other studies indicate that flooding increased sand particle
Table 1 The effects of the reverse seasonal flooding on soil texture

\begin{tabular}{cllll}
\hline Riverbank & Clay particle $(\%)$ & Silt particle $(\%)$ & Sand particle $(\%)$ & Soil texture type \\
\hline Hydro-fluctuation belt & $7.44 \pm 0.11 \mathrm{a}$ & $46.29 \pm 0.46 \mathrm{a}$ & $46.36 \pm 0.24 \mathrm{~b}$ & Silty loam \\
Non hydro-fluctuation belt & $6.86 \pm 0.14 \mathrm{~b}$ & $43.03 \pm 0.31 \mathrm{~b}$ & $50.10 \pm 0.51 \mathrm{a}$ & Loam \\
$F ; p$ & $24.15 ;<0.01$ & $19.57 ; 0.00$ & $15.91 ;<0.01$ & \\
\hline
\end{tabular}

Different letters in the columns indicate significant differences $(P<0.05)$. The following tables are the same 
Table 2 The changes of soil texture along an altitude gradient within the hydro-fluctuation belt

\begin{tabular}{lllll}
\hline Altitude $(\mathrm{m})$ & Clay $(<2 \mu \mathrm{m})(\%)$ & Silt $(2 \sim 20 \mu \mathrm{m})(\%)$ & Sand $(20 \sim 2000 \mu \mathrm{m})(\%)$ & Soil texture \\
\hline 150 & $7.69 \pm 0.41^{\mathrm{a}}$ & $47.99 \pm 2.14^{\mathrm{a}}$ & $44.32 \pm 1.96^{\mathrm{f}}$ & Silty loam \\
155 & $7.71 \pm 0.39^{\mathrm{a}}$ & $46.27 \pm 3.15^{\mathrm{b}}$ & $46.03 \pm 2.64^{\mathrm{e}}$ & Silty loam \\
160 & $6.93 \pm 0.57^{\mathrm{b}}$ & $44.90 \pm 3.53^{\mathrm{c}}$ & $48.16 \pm 2.74^{\mathrm{d}}$ & Loam \\
165 & $6.80 \pm 0.28^{\mathrm{c}}$ & $44.11 \pm 2.54^{\mathrm{d}}$ & $49.09 \pm 3.17^{\mathrm{c}}$ & Loam \\
170 & $6.21 \pm 0.46^{\mathrm{d}}$ & $40.93 \pm 3.78^{\mathrm{f}}$ & $52.86 \pm 3.41^{\mathrm{a}}$ & Loam, sand loam \\
175 & $6.11 \pm 0.61^{\mathrm{e}}$ & $41.95 \pm 4.17^{\mathrm{e}}$ & $51.95 \pm 3.25^{\mathrm{b}}$ & Loam \\
$F ; p$ & $40.51 ;<0.01$ & $6.67 ;<0.01$ & $11.32 ;<0.01$ & \\
\hline
\end{tabular}

percentage, soil bulk density, and soil substrate concentration, inducing soil texture degradation (Campbell et al. 2002). The reverse seasonal flooding caused the riparian soil to experience periodical inundation, exposure, scour, and elution, accompanied by a series of changes in soil oxygen, water content, temperature, and soil microorganism content and metabolism in the Three Gorges reservoir area (Du and Gao 2011). These factors eventually resulted in a dramatic change in riparian soil texture. Our studies indicate that the 6-year disturbance caused by the reverse seasonal flooding significantly changed the soil texture in the hydro-fluctuation belt. The percentage of clay and silt particles increased significantly while the percentage of sand particles decreased significantly. The riparian soil texture completely transitioned from loam to silt loam. Since the river wetland is highly open, much of the flushed soil particles from the riverbank flowed downstream (Noe et al. 2013). This deposition of clay and silt particles from the upstream riverbank and terrestrial system over hydro-fluctuation belt resulted in the significant change in riparian soil texture, under the rain and flood conditions.

This data implicates reverse seasonal flooding in inducing riparian soil changes along the altitude gradient in flooding intensity, flooding frequency, exposure, and submersion season and time span in the hydro-fluctuation belt. Soil in the middle and upper hydro-fluctuation belts suffered a high degree of flooding at high frequency and experienced long-term exposure, while soil in the lower hydro-fluctuation belt was only slightly disturbed by flooding at a lower frequency and experienced long-term submersion. Under the influence of the reverse seasonal flooding, much of the smaller soil particles were washed away in the middle and upper hydro-fluctuation belt and deposited in the lower hydro-fluctuation belt. The percentage of clay and silt particles in the lower hydrofluctuation belt was high, while the percentage of sand particles was lower in the middle and upper hydro-fluctuation belts. This varying presence of sand further differentiated soil texture along altitude gradient. The soil texture in lower hydro-fluctuation belt changed from loam soil to silt loam soil. Du and Gao (2011) conducted detailed research on the distribution of soil particle size in the Three Gorges reservoir by taking Zhongxian as a case study. Their research results coincided with our research results from the four field experimental plots. The reverse seasonal flooding also affected the differentiation of soil texture between soil layers in the riparian zone. While the percentage of clay and silt increased, the percentage of sand decreased with soil depth in both the hydro-fluctuation belt and the non-hydro-fluctuation belt. However, the reverse seasonal flooding reduced the degree of these differences in soil composition between soil layers in the hydro-fluctuation belt.

\subsection{The changes of soil nutrient associated with the variation of soil texture}

The variation of the soil texture was often associated with changes in the chemical composition of soil in wetland evolution and recovery (Campbell et al. 2002; Lu et al. 2007). It is thought that soil particle size is closely related to the retention

Table 3 Changes of riparian soil texture with soil depth

\begin{tabular}{|c|c|c|c|c|c|}
\hline Riverbank & Soil depth (cm) & Clay $(<2 \mu \mathrm{m})(\%)$ & Silt $(2 \sim 20 \mu \mathrm{m})(\%)$ & Sand $(20 \sim 2000 \mu \mathrm{m})(\%)$ & Soil texture type \\
\hline \multirow[t]{3}{*}{ Hydro-fluctuation belt } & $0 \sim 5$ & $6.91 \pm 0.41^{\mathrm{c}}$ & $44.18 \pm 0.24^{\mathrm{c}}$ & $48.92 \pm 0.62^{\mathrm{a}}$ & Loam \\
\hline & $5 \sim 10$ & $7.57 \pm 0.34^{\mathrm{b}}$ & $46.84 \pm 0.31^{b}$ & $45.59 \pm 0.57^{b}$ & Silty loam \\
\hline & $10 \sim 15$ & $7.86 \pm 0.32^{\mathrm{a}}$ & $47.86 \pm 0.26^{\mathrm{a}}$ & $44.58 \pm 0.42^{\mathrm{c}}$ & Silty loam \\
\hline$F ; p$ & & $44.24 ;<0.01$ & $24.76 ;<0.01$ & $81.78 ;<0.01$ & \\
\hline \multirow[t]{3}{*}{ Non hydro-fluctuation belt } & $0 \sim 5$ & $6.86 \pm 0.04^{\mathrm{c}}$ & $43.03 \pm 0.54^{\mathrm{c}}$ & $50.11 \pm 0.49^{\mathrm{a}}$ & Loam \\
\hline & $5 \sim 10$ & $7.84 \pm 0.46^{\mathrm{b}}$ & $47.67 \pm 0.35^{\mathrm{b}}$ & $46.32 \pm 0.39^{\mathrm{b}}$ & Silty loam \\
\hline & $10 \sim 15$ & $8.38 \pm 0.39^{\mathrm{a}}$ & $50.13 \pm 0.41^{\mathrm{a}}$ & $41.48 \pm 0.26^{\mathrm{c}}$ & Silty loam \\
\hline$F ; p$ & & $40.51 ;<0.01$ & $6.67 ;<0.01$ & $11.32 ;<0.01$ & \\
\hline
\end{tabular}


Table 4 The interrelation between soil texture and soil nutrients

\begin{tabular}{cllll}
\hline Soil texture & $\begin{array}{l}\text { Organic matter } \\
\text { Mean } \pm \mathrm{SE}(\mathrm{g} / \mathrm{kg})\end{array}$ & $\begin{array}{l}\text { Total nitrogen } \\
\text { Mean } \pm \mathrm{SE}(\mathrm{g} / \mathrm{kg})\end{array}$ & $\begin{array}{l}\text { Total phosphorus } \\
\text { Mean } \pm \mathrm{SE}(\mathrm{g} / \mathrm{kg})\end{array}$ & $\begin{array}{c}\text { Total potassium } \\
\text { Mean } \pm \mathrm{SE}(\mathrm{g} / \mathrm{kg})\end{array}$ \\
\hline Loam & $15.97 \pm 0.35 \mathrm{a}$ & $0.98 \pm 0.03 \mathrm{a}$ & $1.11 \pm 0.02 \mathrm{a}$ & $9.43 \pm 0.19 \mathrm{a}$ \\
Silty loam & $14.19 \pm 0.28 \mathrm{~b}$ & $0.85 \pm 0.04 \mathrm{~b}$ & $0.99 \pm 0.03 \mathrm{~b}$ & $8.57 \pm 0.23 \mathrm{~b}$ \\
Sand loam & $10.93 \pm 0.21 \mathrm{c}$ & $0.73 \pm 0.03 \mathrm{c}$ & $0.76 \pm 0.02 \mathrm{c}$ & $5.66 \pm 0.14 \mathrm{c}$ \\
$F ; p$ & $34.24 ;<0.01$ & $18.65 ;<0.01$ & $27.21 ;<0.01$ & $25.15 ;<0.01$ \\
\hline
\end{tabular}

of soil nutrients. Soil particles of different sizes, including clay, silt, and sand, have different effects on soil organic matter and nutrient content (Zhou et al. 2009). The percentage of smaller soil particles, including the clay and the silt, has a positive correlation with soil nutrient content, as the presence of small particles increases surface area and cohesion, leading to a higher capacity to adsorb and retain soil nutrients. In contrast, a higher percentage of the sand leads to lowered organic matter content, as the large size particle increased soil looseness and permeability, promoting the formation and transformation of organic matter (Wu et al. 2004; Zhang et al. 2012). Bi et al. (1997) reported that soil organic matter and total nitrogen were concentrated mainly in clay particles, as did total phosphorus and total potassium, even though there was little difference among soil particles.

Flooding was a critical factor regarding the changes in soil texture and soil nutrient in wetland succession; flooding patterns determined the changing trend of soil texture and soil nutrient (Hefting et al. 2004; Zheng et al. 2011). The reverse seasonal flooding resulted in spatial variation of soil texture along the altitude gradient in the Three Gorges reservoir area. Silt loam, which had the highest percentage of clay and the silt, was distributed in the lower hydro-fluctuation belt, while loam with relatively lower percentages of clay and silt was distributed in the middle and upper hydro-fluctuation belts. The sand loam, which has the highest percentage of sand, only appeared in some parts of the upper hydro-fluctuation belt. This change in soil texture resulted in a coordinated change in soil nutrient content. Our research results suggest that the loam soil ranked the highest in soil nutrient content, with excellent soil particle size composition and good permeability. In comparison, silty loam had a lower soil nutrient content, with the highest percentage of small size particles and poor permeability, while sandy loam had the lowest soil nutrient content and the highest percentage of sand particles. These results are in accordance with the soil nutrient characteristics of soil texture, as well as the spatial distribution characteristics of soil nutrients in the Three Gorges reservoir area (Wang et al. 2015; Wang et al. 2016). These studies also suggest that the reverse seasonal flooding caused a loss of soil nutrients and induced an irregular spatial distribution of soil nutrients in that the highest concentrations of soil nutrient were predominantly distributed to the middle hydro-fluctuation belt (Chang et al. 2011; Shen et al. 2016).

\section{Conclusions}

The reverse seasonal flooding resulted from the construction of the Three Gorges dam influences significantly the soil texture and soil nutrient within the hydro-fluctuation belt in the Three Gorges reservoir area. The soil texture is totally changed from loam to silt loam with the deposition of clay and silt within the hydro-fluctuation belt, while a spatial variation of soil texture occurrences from silt loam, loam, then to sand loam with increasing altitude gradient. This change in soil texture is associated with changes in soil nutrients. The content of soil organic matter, total nitrogen, total phosphorus, and total potassium varied significantly among soil texture types. An irregular spatial distribution of soil nutrient occurrences in that the highest concentrations of soil nutrient were predominantly distributed to the middle hydro-fluctuation belt.

Acknowledgments We thank Shoupeng Guan and Tianyi Wu for help with the experiment. We would like to thank Yongchong Li for his patience in refining the manuscript. This work is supported by a National Natural Science Foundation of China (51379105).

Open Access This article is distributed under the terms of the Creative Commons Attribution 4.0 International License (http:// creativecommons.org/licenses/by/4.0/), which permits unrestricted use, distribution, and reproduction in any medium, provided you give appropriate credit to the original author(s) and the source, provide a link to the Creative Commons license, and indicate if changes were made.

\section{References}

Ahmadi A, Neyshabouri MR, Rouhipour H, Asadi H (2011) Fractal dimension of soil aggregates as an index of soil erodibility. J Hydrol 400:305-311

Banach AM, Visser EJW, Stepniewska Z, Smits AJM, Roelofs JGM, Lamers LPM (2009) Effects of summer flooding on floodplain biogeochemistry in Poland; implications for increased flooding frequency. Biogeochemistry 92:247-262

Bi YL, Wang BQ, Guo SLYCZ (1997) The characteristics of soil nutrient in the loess hilly dam land and its relationship with the erosion relationship II. The distribution and nutrient of soil particle size in the dam. J Soil Water Conserv 3:38-44 (in Chinese with English abstract)

Campbell DA, Cole CA, Brooks RP (2002) A comparison of created and natural wetlands in Pennsylvania, USA. Wetl Ecol Manag 10:41-49

Chang C, Xie ZQ, Xiong GM, Chu LM (2011) The effect of flooding on soil physical and chemical properties of riparian zone in the three 
Gorges reservoir. J Nat Resour 26:236-1244 (in Chinese with English abstract)

Christensen T, Straw B (1986) Incorporation and soil organic matter in macro-aggregations and particle size separaties. J Soil Sci 37:125135

Crawford JW, Sleemant BD, Young IM (1993) On the relation between number-size distributions and the fractal dimension of aggregates. Eur J Soil Sci 44:555-565

Du GZ, Gao MR (2011) The distribution and fractal characteristics of typical soil particle in the water-level fluctuation zone. J Nanjing Forest Uni 35:47-50 (in Chinese with English abstract)

Fu YL, Zhang XC, Wang JG (2012) Fractal dimension of soil particle size distribution characteristics in dry valley of upper min Jiang river. T Chinese Soc Agr Eng 5:120-125 (in Chinese with English abstract)

Guo QS, Kang Y, Zhao YJ, Hong M, Kong QQ, Nie BH (2012) Changes in the content of $\mathrm{N}, \mathrm{P}, \mathrm{K}, \mathrm{pH}$ and organic matter of the soil which experienced water-level fluctuation in three Gorges reservoir. Sci Silval Sin 48:8-10 (in Chinese with English abstract)

Hefting M, Clément JC, Dowrick D, Cosandey AC, Bernal S, Cimpian C, Tatur A, Burt TP, Pinay G (2004) Water table elevation controls on soil nitrogen cycling in riparian wetlands along a European climatic gradient. Biogeochemistry 67:113-134

Hossler K, Bouchard V (2010) Soil development and establishment of carbon-based properties in created freshwater marshes. Ecol Appl 20:539-553

Lee H, Alday JG, Cho K-H, Lee EJ, Marrs RH (2014) Effects of flooding on the seed bank and soil properties in a conservation area on the Han River, South Korea. Ecol Eng 70:102-113

Lin XQ, Li ZP (2001) The decomposition of organic material in red soil. Acta Ecol Sin 22(8):1224-1230 (in Chinese with English abstract)

Lu JW, Wang HJ, Wang WD, Yin CQ (2007) Vegetation and soil properties in restored wetlands near Lake Taihu, China. Hydrobiologia 581:151-159

Lu ZJ, Li LF, Huang HD, Tao M, Zhang QF, Jiang MX (2010) The effect of storing water in the Three Gorges reservoir area on plants in the water-level fluctuation. J Wuhan Bot Res 28303-314 (in Chinese with English abstract)

Lu QQ, Bai JH, Fang HJ, Wang JJ, Zhao QQ, Jia J (2016) Spatial and seasonal distributions of soil sulfur in two marsh wetlands with different flooding frequencies of the Yellow River Delta, China. Ecol Eng 96:63-71

Neill C (1995) Seasonal flooding, nitrogen mineralization and nitrogen utilization in a prairie marsh. Biogeochemistry 30:171-189

Neyshabouri MR, Ahmadi A, Rouhipour H, Asadi H, Irannajad M, Neyshabouri MR (2011) Soil texture fractions and fractal dimension of particle size distribution as predictors of interrill erodibility. Turk J Agric For 35:95-102

Noe GB, Hupp CR, Rybicki NB (2013) Hydrogeomorphology influences soil nitrogen and phosphorus mineralization in floodplain wetlands. Ecosystems 16:75-94

Saint-Laurent D, Gervais-Beaulac V, Berthelot J-S (2014) Variability of soil properties in different flood-risk zones and link with hydroclimatic changes (southern Québec, Canada). Geoderma 214-215:80-90

Shen YF, Wang N, Liu ZB, Wang XR, Xiao FW, Cheng RM (2016) The chemical changes of soil in the three Gorges water-level fluctuation zone. J Soil Water Conserv 30:190-195 (in Chinese with English abstract)
Wang HJ, Li XW, Shi XZYDS (2003) Distribution of soil nutrients under different land use and relationship between soil nutrient and soil granule composition. J Soil Water Conserv 17:44-50 (in Chinese with English abstract)

Wang SR, Jin XC, Pang Y, Zhao HC, Zhou XN, Wu FC (2005) Phosphorus fractions and phosphate sorption characteristics in relation to the sediment compositions of shallow lakes in the middle and lower reaches of Yangtze River region China. J Colloid Interf Sci 289:339-346

Wang D, Fu BJ, Chen LD, Zhao WW (2007) Under different land use type soil particle size distribution fractal analysis - such as loess hilly-gully region. Acta Ecol Sin 27:3081-3089 (in Chinese with English abstract)

Wang F, Jia ZJ, Dong Z, Li HL, Zhen BY, Sun MG, Zhan WP (2009) Fractal features of soil particle size distribution on water source conservation areas under different measures of ecological restoration. J Soil Water Conserv 23:113-117 (in Chinese with English abstract)

Wang YH, He X, Hai Miti Y (2014) Analysis of soil granularity in Ebinur lake wetland. Agr Res Arid Areas 32:183-187 (in Chinese with English abstract)

Wang LG, Gao YH, Ding CH (2015) Distribution characteristics of soil organic carbon in a typical water-level-fluctuation zone of the three Gorges reservoir area. J Southwest Uni 37:120-124 (in Chinese with English abstract)

Wang YJ, Chen FQ, Zhang M, Wu Y, Chen SH (2016) Characteristics of soil nutrient and spatial distribution on riparian zone restored by different vegetation restoration methods at Wanzhou section in the three Gorges reservoir area, China. J Agr Resour Environ 33:127133 (in Chinese with English abstract)

Wolf KL, Ahn C, Noe GB (2011) Development of soil properties and nitrogen cycling in created wetlands. Wetlands 31:699-712

Wu QB, Wang XK, Zhang DP, Guo Y (2004) Effect of clay-silt fractions of soil on SOC and TN in Hulunbeir grassland. Ecol Environ 13: 630-632 (in Chinese with English abstract)

Xu GC, Li ZB, Li P (2013) Fractal features of soil particle-size distribution and total soil nitrogen distribution in a typical watershed in the source area of the middle Dan River, China. Catena 101:17-23

Yang JG, An SS, Zheng FL (2006) Characteristics of soil water stable aggregates and relationship with soil properties during vegetation rehabilitation in Ninxia loess hilly region. J Soil Water Conserv 20(72-75):98 (in Chinese with English abstract)

Ye XF, Bai JH, Lu QQ, Zhao QQ, Wang JJ (2014) Spatial and seasonal distributions of soil phosphorus in a typical seasonal flooding wetland of the Yellow River Delta, China. Environ Earth Sci 71:48114820

Zhang JH, Li GD, Nan ZG, Xiao HL (2012) Research on soil particle size distribution and its relationship with soil organic carbon under the effects of tillage in the Heihe oasis. Geogr Res 31:608-618

Zheng ZW, Zou X, An R, Zhang ZY, Hu L, Wan CY, Hu HQ (2011) Soil physical and chemical properties in water-level-fluctuation zone in Xiaojiang watershed in three Gorges reservoir. J Hydroecol 32:1-6 (in Chinese with English abstract)

Zhou XF, Zhao R, Li YY, Chen XY (2009) Effects of land use types on particle sizes distribution of reclaimed alluvial soils of the Yangtze estuary. Acta Ecol Sin 29(10):5544-5551 (in Chinese with English abstract) 